\title{
GHG emissions in KG-CO 2 / M2 generated by a House Type INFONAVIT
}

\section{Emisiones de GEI en KG-CO2 /M2 generados por una Vivienda Tipo INFONAVIT}

ACEVES-GUTIERREZ, Humberto †*, LÓPEZ-CHÁVEZ, Oscar, MERCADO-IBARRA，Santa Magdalena and CONTRERAS-QUINTANAR, Cesar Alejandro

\author{
Instituto Tecnológico de Sonora
}

ID $1^{\text {st }}$ Author: Humberto, Aceves-Gutierrez / ORC ID: 0000-0001-9916-3114, Researcher ID Thomson, F-8970-2018, CVU CONACYT ID: 2811581

ID 1 st Coauthor: Oscar López-Chávez, ORC ID: 0000-0002-0568-2763

ID $2^{\text {nd }}$ Coauthor: Santa Magdalena, Mercado-Ibarra / ORC ID: 0000-0002-4417-0736, Researcher ID Thomson, H-33862018, CVU CONACYT ID: 258533

ID $3{ }^{\text {st }}$ Coauthor: Cesar Alejandro, Contreras-Quintanar / ORC ID: 0000-0002-0553-7515, arXiv Author ID: cesarcq, CVU CONACYT ID: 972613

DOI: $10.35429 / E J R N .2019 .8 .5 .15 .28$

Received April 08, 2019; Accepted May 30, 2019

\begin{abstract}
Climate change is one of the main current problems, it concerns the entire human population since its effects are worldwide, especially now we have seen its consequences, according to Menghi (2007), the average global temperatures grew by more than $0.5^{\circ} \mathrm{C}$ in the last century, and the glaciers are disappearing from the earth. The greenhouse effect generated mainly by the gases of the same name $(\mathrm{GHG})$, is the fundamental factor of climate change. Construction is one of the ways in which the human being contaminates in a constant way this due to urban growth and the demand for infrastructure that this generates. This research has the purpose of determining the $\mathrm{KG}-\mathrm{CO}_{2}$ / M2 generated by a $44 \mathrm{~m} 2$ house of interest type INFONAVIT using the Life Cycle methodology (ACV) of the products or materials, established in ISO 14040 , employee an inventory of $\mathrm{KG}-\mathrm{CO}_{2}$ emissions from building materials, obtained from various bibliographic sources and databases and using the work volumes required to build the house. The results obtained of 161.57 $\mathrm{Kg}-\mathrm{CO}_{2} / \mathrm{M} 2$.
\end{abstract}

House, GHG, KG-CO2/M2

\section{Resumen}

El cambio climático es uno de los principales problemas actuales, concierne a toda la población humana ya que sus efectos son de alcance mundial, especialmente en la actualidad hemos visto sus consecuencias, según Menghi (2007), las temperaturas promedio mundiales crecieron en más de $0.5^{\circ} \mathrm{C}$ en el último siglo y los glaciares están desapareciendo de la tierra. El efecto invernadero generado principalmente por los gases del mismo nombre (GEI), es el factor fundamental del cambio climático. La construcción es una de las formas a través de las que el ser humano contamina de una manera constante esto debido al crecimiento urbano y la demanda de infraestructura que ello genera. Esta investigación tiene como propósito la determinación de los $\mathrm{KG}-\mathrm{CO}_{2} / \mathrm{M} 2$ que genera una vivienda de 44 M2 de construcción interés tipo INFONAVIT empleando la metodología de Ciclo de Vida (ACV) de los productos o materiales, establecida en la norma ISO 14040, empleado un inventario de emisiones de $\mathrm{KG}-\mathrm{CO}_{2}$ de materiales de construcción, obtenidos de diversa Sources bibliográficas y bases de datos y empleando los volúmenes de obra requeridos para construir la vivienda. Los resultados obtenidos de 161.57 $\mathrm{Kg}-\mathrm{CO}_{2} / \mathrm{M} 2$.

Vivienda, GEI, KG-CO2/M2

Citation: ACEVES-GUTIERREZ, Humberto, LÓPEZ-CHÁVEZ, Oscar, MERCADO-IBARRA, Santa Magdalena and CONTRERAS-QUINTANAR, Cesar Alejandro. GHG emissions in KG-CO2 / M2 generated by a House Type INFONAVIT. ECORFAN Journal-Republic of Nicaragua. 2019 5-8: 15-28

\footnotetext{
* Correspondence to Author (email: haceves_itson@ hotmail.com)

$\dagger$ Researcher contributing as first author.
} 


\section{Introduction}

Global warming is the effect caused by the high amount of greenhouse gases (GHG) that accumulate in the atmosphere, preventing the solar rays that enter the earth bounce and escape into the atmosphere, to the contrary, bounce back to the earth's surface thus achieving heat to gather in the earth's crust and the biggest affected are the living beings that live in it, in this work we will focus specifically on the effects on human beings.

The environmental impact that industries have on the environment and natural resources has been considerable, not only as a result of production growth but also because this growth was concentrated in sectors with high environmental impact. (SEMARNAT, 2010).

It is important to be aware of the consequences that this may have on our health.

Recent studies have described a significant number of adverse effects of ozone, the most important ones related to the respiratory system, such as decreased lung function, worsening asthma, increased risk of emergency visits, hospital admissions and, probably, an increase of risk of dying. On the other hand, there is some evidence that individuals, especially younger ones, with hyperreactivity of airways, such as asthmatics, constitute a group more sensitive to the effects of ozone (Ballester, 2005).

The ozone concentration has increased in the atmosphere to almost eight times the natural atmospheric concentration, causing in the people respiratory system alterations, headache, burning eyes and skin infections (Montaño \& Sandoval, 2007).

The study conducted by Pope and colleagues as part of the II Study for the Prevention of Cancer, which was published in March 2002, concluded that fine particles (PM2.5) and sulfur oxides showed an association with mortality for all the causes, for diseases of the circulatory system and for lung cancer. Each $10 \mu \mathrm{g} / \mathrm{M} 3$ increase in atmospheric levels of fine particles was associated approximately with an increase of $4 \%, 6 \%$, and $8 \%$, respectively, of the risk of dying from all causes, from the circulatory system and from lung cancer (Ballester, 2005).
Mexico annually emits 188 million tons of carbon (C), that is, about $2 \%$ of global greenhouse gas emissions and ranks as the ninth country in this area worldwide. Directly $\mathrm{CO} 2$ causes heart failure, suffocation and even death to exposed people. This occurs because $\mathrm{CO} 2$ replaces the oxygen in the red blood cells and reduces the amount that should reach the cells of the body to keep it alive, so it affects all people, but even more so with those with diseases cardiovascular, cerebral and respiratory. Indirectly, $\mathrm{CO} 2$ favors the increase in temperature to a degree Celsius $\left({ }^{\circ} \mathrm{C}\right)$ which can cause the presence of mosquitoes in regions where the cold prevented them from surviving and reproducing; many of them are vectors of diseases such as: malaria transmitted by the Anopheles mosquito, encephalitis transmitted by the Culex mosquito and dengue virus and Nile fever transmitted by the Ades aegypti mosquito.

Also, an increase in temperature could allow the appearance of microorganisms that generate new diseases. The increase in temperature also affects agricultural systems, where severe droughts and the emergence of pests can reduce the quantity and quality of food (Montaño \& Sandoval, 2007).

The World Health Organization (WHO) has estimated a number of deaths attributable to climate change of 160,000 per year. Heat waves will be more frequent and extreme in some areas of Europe and North America for the second half of the 21st century (Gonzales, Fernández \& Gutiérrez, 2013).

For this reason it is considered very important to look for ways to reduce greenhouse gases (GHG), especially $\mathrm{CO} 2$, which is the most abundant after water vapor. Carbon dioxide (CO2) is the second most important GHG since it is added to the atmosphere both naturally and anthropogenicly (global warming).

Throughout the history of the Earth, volcanoes have naturally added it, and it has been recycled through multiple natural pathways that carbon follows in nature. Without the presence of $\mathrm{CO} 2$, the temperature on the Earth's surface would be about $33^{\circ} \mathrm{C}$ lower than the current one, which would be hostile to life. But $\mathrm{CO} 2$ is also added unnaturally, as a result of common human activities, mainly due to the burning of fossil fuels and the destruction (nowadays) of the rainforest. 
Being the main contributor to global warming with $55 \%$ (Echeverri, 2006), it has been decided by different organizations and countries worldwide to focus efforts towards global emissions of $\mathrm{CO}_{2}$.

According to the Classification of Individual Consumption According to Purpose (COICOP), more than $80 \%$ of the total emissions associated with the private consumption of Spanish households is due to the expenditure incurred in: "transport and communications", "food, beverages and tobacco", "leisure, culture and hospitality ", "electricity, gas and other fuels "and" articles of clothing and footwear". The remaining $20 \%$ corresponds to the expenditure on "housing and water", "other goods and services", "furniture, equipment and conservation of housing" and "health and education (private)" (Serrano, 2019).

On the other hand Shen. et al. (2005) argues that construction is the main source of environmental pollution compared to other industries. In the European Union the construction sector generates $36 \%$ of $\mathrm{CO} 2$ emissions, it is the one that consumes the most energy and the one that generates the most waste, and also uses $60 \%$ of the materials that are extracted in the continent (Bravo, 2011).

$60 \%$ of the materials that are extracted from the lithosphere, are destined for construction. $50 \%$ of the $\mathrm{CO} 2$ emissions emitted into the atmosphere have their origin in the construction and use of buildings. $40 \%$ of the primary energy consumed on the planet and $75 \%$ of the electricity allocated is aimed at buildings. $20 \%$ of fresh water is consumed in the use of buildings. $60 \%$ of solid waste is produced in the construction and destruction of buildings (Casanovas, 2009).

That is why special attention should be paid to the construction sector, in order to predict how many $\mathrm{CO} 2$ emissions could be emitted. Analyzing the Population and Housing Census 2010 and the 2015 Intercensal Survey of INEGI (2015), it can be seen how in those 5 years the number of homes grew by $14.42 \%$ in Sonora; the number of dwellings, translated into figures, would be 102,712 new dwellings in a period of 5 years, and if we compare with the II Population and Housing Count 2005 of the INEGI (2005) the same trends are observed, from 2005-2010 the number of housing increase $15.86 \%$ or 97.513 housing is the same.

ISSN 2414-8830

ECORFAN® All rights reserved

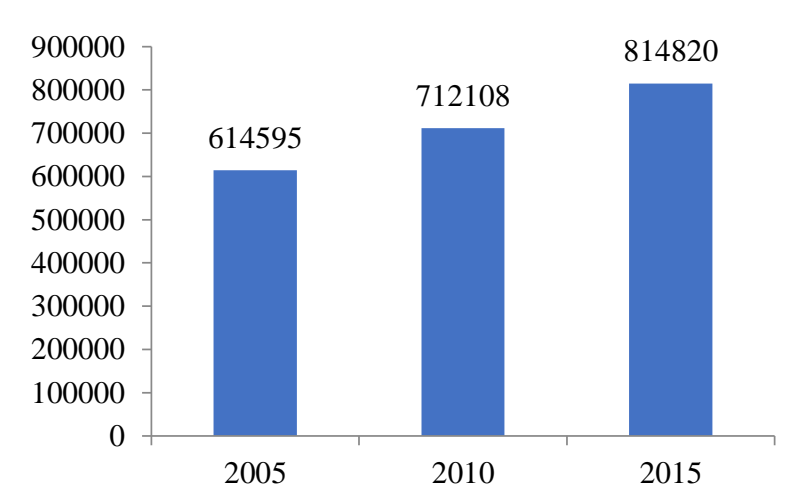

Graphic 1 Private homes inhabited in Sonora in the period 2005, 2010 and 2015

Source: INEGI. II Conteo de Población y Vivienda 2005, INEGI. Censo de Población y Vivienda 2010, INEGI(2010). Encuesta Intercensal 2015

In (CONAPO, 2018) "Demographic indicators of Mexico from 1950 to 2050 and of the federal entities from 1970 to 2050 " tells us that Sonora has a total annual growth rate of 37,397.5 inhabitants in 2019 and in 2030 that rate will remain positive having a number of 30,267.5 inhabitants. In the "Household Projections" database of the National Housing Commission (CONAVI), the national and state data of the homes estimated until 2030 were obtained.

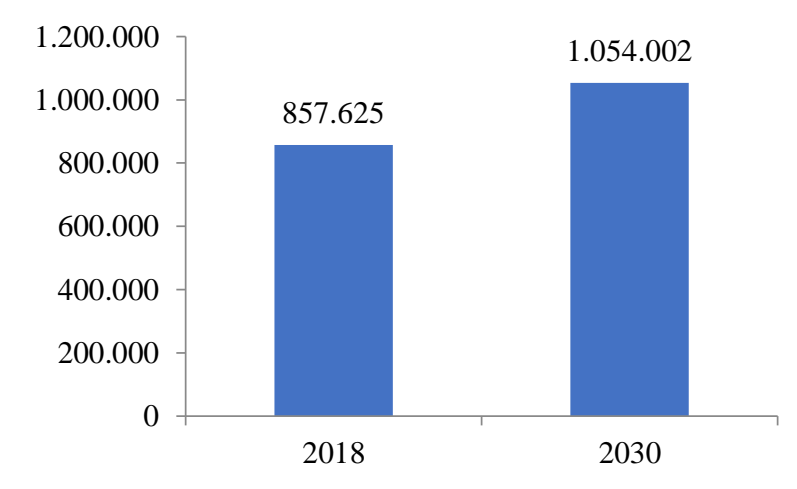

Graphic 2 Number of estimated Homes in Sonora in the period 2018 and 2030

Source: Prepared by CONAVI with information on CONAPO projections

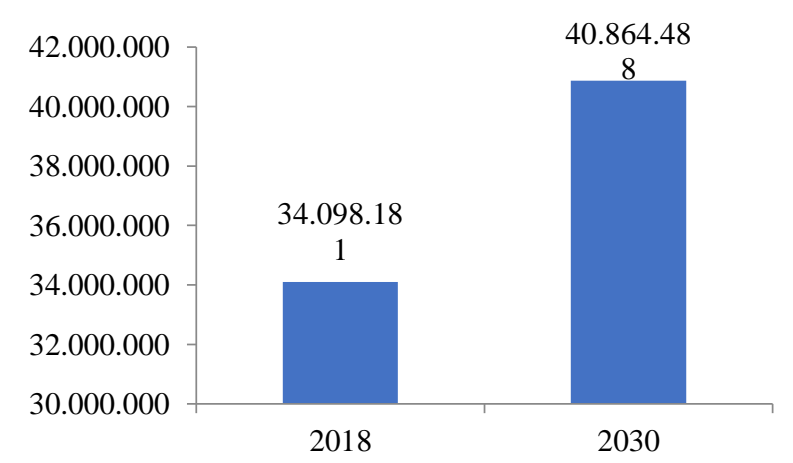

Gráfico 3 Number of estimated homes in Mexico in the period 2018 and 2030

Source: Prepared by CONAVI with information on CONAPO projections

ACEVES-GUTIERREZ, Humberto, LÓPEZ-CHÁVEZ, Oscar, MERCADO-IBARRA, Santa Magdalena and CONTRERASQUINTANAR, Cesar Alejandro. GHG emissions in KG-CO2 / M2 generated by a House Type INFONAVIT. ECORFAN Journal-Republic of Nicaragua. 2019 
By 2030 there will be an increase in the number of homes nationwide of 6,766,307, and at the state level speaking of Sonora it will be 196,377 , compared to 2018 that gives us a great basis to determine the amount of GHG that will be thrown at the atmosphere in the next 12 years.

Several research projects have taken on the task of investigating the environmental impact of the materials consumed in the construction of a house, as is the case of (Mercader, 2012) "Model for quantification of $\mathrm{CO} 2$ emissions produced in buildings derived from resources materials consumed in its execution "where the $\mathrm{CO} 2$ emissions produced in the execution of the usual construction model defined as the residential block destined for official housing are quantified, derived from the manufacturing process of the material resources used in its execution. Others have focused on an economic point of view as in (Estrada, 2014) "implement carbon footprint reduction and compensation measures in their construction projects" where they analyze it with the objective of finding how feasible it is, from the point of technical and economic view, implement carbon footprint reduction and compensation measures in its construction projects.

Within the above-mentioned investigations, different ways of determining GHGs are presented, in the first case the steps proposed by the GHG Protocol are followed, which is a model that establishes comprehensive and comprehensive frameworks to measure and manage GHG emissions from operations of the private and public sector, value chains and mitigation actions (World Resources Institute and the World Business Council for Sustainable Development, 2019), when measuring emissions, the protocol indicates that we must add the amount of a specific material and then multiply it by its emission factor. The protocol does not offer emission factors, but mentions that if there are no local, regional or countryspecific sources available, predetermined factors of the Intergovernmental Panel on Climate Change should be used. (IPCC).

In the second investigation, the form used to calculate the carbon footprint proposes a series of steps within which they begin with the selection of the calculation methodology, if you have a business approach you should use GHG Protocol, If you focus on a product, you must resort to the PAS 2050 standard.
Then you define the limits for accounting for GHG emissions, according to the selected methodology. Next, any field or record data that allows quantifying the processes and operations defined in the previous step should be collected. And finally, the carbon footprint must be calculated by multiplying the data obtained in the previous step by an appropriate emission factor (Estrada, 2014). It can be observed in both cases the similarity between them in the aspect of quantifying emissions, it is essentially the same even as it is observed both cases are used or considered the GREENHOUSE GAS (GHG) Protocol, which is based primarily on quantifying the total of each material and then multiply by its emission factor.

In an effort to have a better perspective on the amount of emissions produced by the construction industry, it was decided to investigate the amount of emissions that are had in the construction of a house located in Ciudad Obregón, Sonora, in a social interest subdivision with an area of $43.87 \mathrm{M} 2$, built with block walls, foundation slab and polystyrene slab and vault slab system, based on the background obtained, we chose to record the emissions by adding the product quantities and multiplying them by their emission factor, considering the materials that are used in quantities of significant enough size in the work. The life cycle analysis (LCA) is considered as an environmental tool that can provide a better understanding of the dimensions of the environmental profile of products, processes and services. It is a suitable tool to compare potential environmental impacts of various product alternatives. Combined with economic and social considerations, life cycle analysis can be used to analyze product sustainability (Anonymous, 2004).

Depending on the processes contemplated by the LCA, it may have different scopes:

"From the cradle to the grave": Includes the extraction of raw materials and the processing of the necessary materials for component manufacturing, the use of the product and finally its recycling and/or final management. Transport, storage, distribution and other intermediate activities between the life cycle phases are also included when they are of sufficient relevance (Badilla, Elizondo, Fernández, Mora, Méndez \& Quesada, 2015).

ACEVES-GUTIERREZ, Humberto, LÓPEZ-CHÁVEZ, Oscar, MERCADO-IBARRA, Santa Magdalena and CONTRERASQUINTANAR, Cesar Alejandro. GHG emissions in KG-CO2 / M2 generated by a House Type INFONAVIT. ECORFAN Journal-Republic of Nicaragua. 2019 
- $\quad$ "From the cradle to the door": The scope of the system is limited from when raw materials are obtained until the product is placed on the market, at the exit of the manufacturing plant (Badilla, Elizondo, Fernández, Mora, Méndez \& Quesada, 2015).

"From door to door": Only manufacturing processes are taken into account (Badilla, Elizondo, Fernández, Mora, Méndez \& Quesada, 2015).

The dwelling studied was taken as a product, to which the LCA was applied, in order to better measure its environmental impact. To achieve a correct methodology with the life cycle, the first thing that was done was to define a calculation method, which depending on the approach can be selected from one of the existing ones. A common dwelling was analyzed and selected in the national context, from which the explosion of inputs (materials, labor, machinery and equipment) required for the construction of the dwelling was obtained, as a result of the quantification of each of them. Finally, the scope of the study (cradle at the door) was selected and the corresponding emission factors were searched and selected.

With the results obtained, the damages to which the atmosphere will be exposed can be predicted and in this way actions can be initiated with the purpose of improving the conditions of the atmosphere today. The results can also be applied to the national territory in works of similar characteristics and will be usable information to determine in a practical way the GHG emissions generated in the housing construction stage.

\section{Methodology}

To carry out this project, the participation of a student and civil engineering research professors from the Technological Institute of Sonora was carried out, making the pertinent calculations to obtain results, the materials and equipment used were, the Excel electronic sheet for the visualization of the explosion of inputs and to capture the data created to quantify the $\mathrm{CO} 2$ emissions generated by the construction, interpretation of results. The sources of information were previous works related to the project such as thesis, articles, scientific journals, database of the Mexican government, electronic bibliography in general.
Procedure:

1. It began by choosing a project of a very common INFONAVIT housing in the national context, in order to have a representative figure in the entire national context, from this the explosion of inputs related to the materials used in its construction and the construction Plan of the work.

2. A calculation methodology was defined, as it focused on the use of emission factors, the GHG PROTOCOL and the LIFE CYCLE ASSESMENT ISO 14040 were used as a basis, making the appropriate adjustments to the context of the study.

3. The explosion of inputs of the materials used in a study dwelling was used, then began to discard materials that are used in small quantities and that are not repeated. The remaining materials were ordered and in cases where there are composite materials they were separated into their components and each material was calculated as individual and then assembled into a single concept.

4. The scope of the LCA was selected as "Cradle at the door" since the period of use of the house and the final disposal of waste at the end of its useful life was not contemplated.

5. The emission factors to be used for the calculation of the emission inventory in the established project were determined.

6. The materials relevant to the input explosion were multiplied by their emission factor and recorded in the Excel electronic sheet.

7. The results of $\mathrm{Kg}-\mathrm{CO} 2 / \mathrm{M} 2$ from the housing input explosion were obtained and the information was therefore interpreted. 


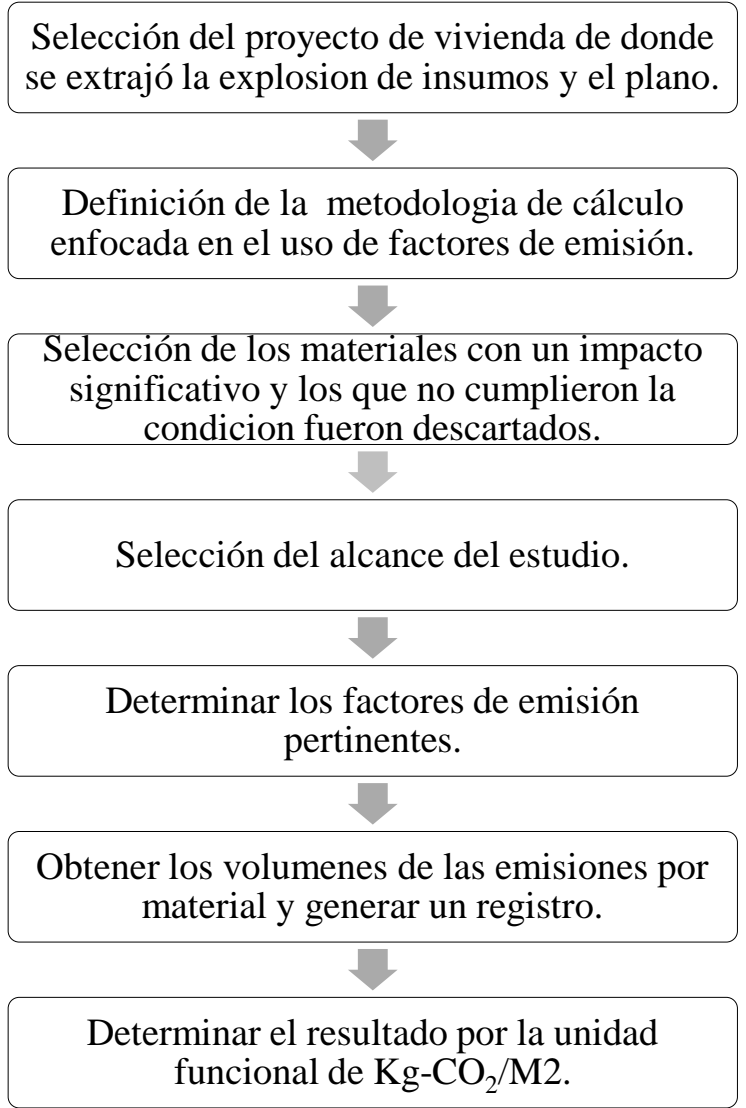

Gráfico 4 Diagrama de flujo de la metodología Source: Own elaboration

\section{Emission factors}

It is explained in a concise manner how the emission factors of each material were chosen, which factors influenced their choice and if they have any conditions in their use.

It was investigated in (Rodríguez, 2010) "Emission factors of construction materials" where the main factors of gray construction materials were obtained from the carbon calculator developed by the author. At the same time in (Argüello, 2008) "Analysis of the environmental impact associated with the construction materials used in the low-cost housing of the $10 \times 10$ Techo-Chiapas program of the CYTED", for example, the emission factor used for the steel, where (Mercader, 2012) "Quantification model of $\mathrm{CO} 2$ emissions produced in buildings derived from the material resources consumed in its execution" determines different additional emission factors to obtain a more reliable database. Additionally also in (Suárez, 2014) "Environmental viability of gypsum recycling" the cast factor was specifically sought. Finally, in "Emission factors for the different types of fossil fuels and alternative that is common in Mexico" developed by the Mexican Petroleum Institute in 2014, the wood emission factor was obtained.
Another source that was taken into account was the (SEMARNAT, 2019) National Emissions Registry (RENE) which shows the official steps to register the emissions of the company or organization with the Mexican government, with an updated emissions calculator and with National data provided by the Ministry of Environment and Natural Resources (SEMARNAT) shows indicative results, some emission factors were obtained from it.

An international data source was the (Circular Ecology, 2019) Inventory of Carbon and Energy (ICE) Version 2.0 of the University of Bath, where various emission factors of different materials were found.

Through research in the sources cited and others, the emission factors for each material were reached.

\section{Composite materials}

As mentioned in the methodology, there are some materials that by their nature are composed of various materials such as, the case of concrete that require cement, gravel, sand and water for their preparation or the case of cement-sand mixtures, mortar-sand, lime-sand that also require combining various materials for its preparation and final presentation, in the specific case of this work are the joists from which it was better to separate the different emission factors that are used in the different materials and in the end just show the value of emissions generated.

The joist is composed of a concrete base and a triangular structure of steel rods, so in that case it was counted for the concrete how many M3 would be used and the quantities of material needed to create the concrete were calculated.

\begin{tabular}{|l|r|r|r|}
\hline \multicolumn{4}{|c|}{ Concreto f'c $=250 \mathrm{Kg} / \mathrm{cm} 2$ para cada M3 } \\
\hline \multicolumn{4}{|c|}{ Tamaño máximo $20 \mathrm{~mm}(3 / 4 ")$} \\
\hline Material & Cant. & $\mathrm{N}^{\circ}$ de M3/vigueta & Total \\
\hline Cemento $(\mathrm{kg})$ & $390^{1}$ & 0.01704 & 6.65 \\
\hline Grava (kg) & $1000^{1}$ & 0.01704 & 17.04 \\
\hline Arena $\mathrm{n}^{\circ} 4(\mathrm{~kg})$ & $790^{1}$ & 0.01704 & 13.46 \\
\hline Agua (lt) & $205^{1}$ & 0.01704 & 3.49 \\
\hline
\end{tabular}

Tabla 1 Cantidad de material para el concreto de la vigueta V-284 armada con 2 Ø 3/16" y refuerzo adicional $1 \varnothing 3 / 16 "$

Source: ${ }^{1}$ CEMEX Concretos, Manual del Constructor. 
With the results obtained, their respective emission factor was applied, then multiplied by the number of pieces and concrete emissions were counted.

\begin{tabular}{|c|c|c|c|}
\hline \multicolumn{4}{|c|}{$\begin{array}{c}\text { Concreto f'c }=250 \mathrm{Kg} / \mathrm{cm} 2 \text { para cada M3 } \\
\text { Tamaño máximo } 20 \mathrm{~mm}(3 / 4 ")\end{array}$} \\
\hline Total & F. Emisión & $\mathrm{N}^{\circ}$ Piezas & Total $\mathrm{CO}_{2}$ \\
\hline $6.65^{*}$ & $0.513^{1}$ & 14 & 47.729 \\
\hline $17.04 * *$ & $0.03^{2}$ & 14 & 7.157 \\
\hline 13.46 *** & $0.03^{2}$ & 14 & 5.654 \\
\hline $3.49 * * * *$ & $0.00003^{2}$ & 14 & 0.001 \\
\hline
\end{tabular}

Tabla 2 Total, de emisión del concreto de la vigueta $V$ 284 armada con 2 Ø 3/16" y refuerzo adicional 1 Ø 3/16" Source: ${ }^{\prime}$ SEMARNAT. RENE, ${ }^{2}$ Mercader. Modelo de cuantificación de las emisiones de $\mathrm{CO}_{2}$ producidas en edificación derivadas de los recursos materiales consumidos en su ejecución

But the steel also makes up the joist, for the steel it was quantified how much steel is needed to meet the specifications of the rods that are needed and the emission factor was applied and the partial emissions of the steel were obtained.

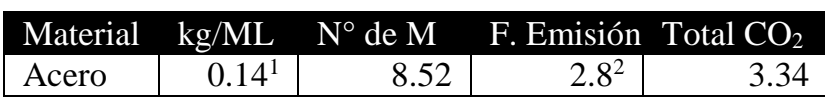

Tabla 3 Cantidad de material de acero para la vigueta V284 armada con 2 Ø 3/16" y refuerzo adicional 1 Ø $3 / 16$ Source: 'Salazar. Costo y tiempo en edificación, ${ }^{2}$ Mercader. Modelo de cuantificación de las emisiones de $\mathrm{CO}_{2}$ producidas en edificación derivadas de los recursos materiales consumidos en su ejecución.

Then it was multiplied by the number of pieces and the total $\mathrm{CO}_{2}$ emissions were achieved.

\begin{tabular}{|l|r|r|r|}
\hline \multicolumn{1}{|c|}{ Material } & Total $\mathrm{CO}_{2}$ & $\mathrm{~N}^{\circ}$ Piezas & Total $\mathrm{CO}_{2}$ \\
\hline Acero & 3.34 & 14 & 46.76 \\
\hline
\end{tabular}

Tabla 4 Total, de emisión del acero de la vigueta V-284 armada con 2 Ø3/16" y refuerzo adicional 1 Ø 3/16" Source: Own elaboration

With both calculated emissions, they were added and thus it was possible to have a total emission value for the joist of $107.30 \mathrm{~kg}-$ $\mathrm{CO} 2$, which is not applicable for the other joists, unless they have the same specifications.

Following this methodology with all composite materials, the relevant emissions are obtained. (annexes)

\section{Results}

Next, the data obtained in the study are presented in tables.

\begin{tabular}{|l|l|l|}
\hline Material & \multicolumn{1}{l|}{ Unidad } & \multicolumn{1}{l|}{ Factor de emisión } \\
\hline Azulejo cerámico & $\mathrm{M} 2$ & $23.22^{1}$ \\
\hline Poliestireno & $\mathrm{kg}$ & $3.43^{2}$ \\
\hline PVC y CPVC & $\mathrm{kg}$ & $3.1^{3}$ \\
\hline Pintura & $\mathrm{kg}$ & $2.91^{3}$ \\
\hline Acero & $\mathrm{kg}$ & $2.8^{1}$ \\
\hline Madera & $\mathrm{kg}$ & $2.314^{4}$ \\
\hline Block $12 \times 20 \times 40 \mathrm{~cm}$ & Pieza & $0.604^{5}$ \\
\hline Cal & $\mathrm{kg}$ & $0.59^{6}$ \\
\hline Cemento & $\mathrm{kg}$ & $0.513^{6}$ \\
\hline Block $12 \times 20 \times 20 \mathrm{~cm}$ & $\mathrm{Pieza}$ & $0.302^{5}$ \\
\hline Block $12 \times 10 \times 40 \mathrm{~cm}$ & $\mathrm{Pieza}$ & $0.302^{5}$ \\
\hline Mortero & $\mathrm{kg}$ & $0.2268^{1}$ \\
\hline Yeso & $\mathrm{kg}$ & $0.072525^{7}$ \\
\hline Grava & $\mathrm{kg}$ & $0.03^{1}$ \\
\hline Arena & $\mathrm{kg}$ & $0.03^{1}$ \\
\hline Agua & $\mathrm{M} 3$ & $0.03^{1}$ \\
\hline & & \\
\hline
\end{tabular}

Tabla 5 Factores de emisiones en $\mathrm{kg}-\mathrm{CO}_{2} /$ Unidad de material

Source: ${ }^{1}$ Mercader. Modelo de cuantificación de las emisiones de $\mathrm{CO}_{2}$ producidas en edificación derivadas de los recursos materiales consumidos en su ejecución, ${ }^{2}$ Pedreño. Desarrollo de una aplicación para el cálculo de la huella de carbono en proyectos de construcción, ${ }^{3}$ Hammond \& Jones. ICE, ${ }^{4}$ SEMARNAT, Factores de emisión para los diferentes tipos de combustibles fósiles y alternativos que se consumen en México, ${ }^{5}$ Rodríguez. Calculadora de carbono para materiales básicos de construcción de obra gris en Costa Rica, ${ }^{6}$ SEMARNAT. RENE, ${ }^{7}$ Suárez. Viabilidad ambiental del reciclaje del yeso

\begin{tabular}{|c|c|c|c|c|}
\hline Material & Peso & $\mathrm{CO}_{2} / \mathrm{Ud}$ & Pzas. & Total $\mathrm{CO}_{2}$ \\
\hline $\begin{array}{l}\text { Block Entero } 12 \times 20 \times 40 \\
(\mathrm{~kg})\end{array}$ & 1 & $0.604^{1}$ & 834.9 & 504.28 \\
\hline Block Dala $12 \times 20 \times 40$ & 1 & $0.604^{1}$ & 145 & 87.58 \\
\hline Block Esquina $12 \times 20 \times 40$ & & $0.604^{1}$ & 138.99 & 83.95 \\
\hline Block Ajuste 12x20x32 & & $0.604^{1}$ & 108.99 & 65.83 \\
\hline Block Mitad 12×20x20 & & $2^{1}$ & 91.99 & 27.78 \\
\hline Block Piña 12x10x40 & 1 & $0.302^{1}$ & 58.96 & 17.81 \\
\hline Block Dala $12 \times 20 \times 40$ & 1 & $0.604^{1}$ & 16 & 9.66 \\
\hline $\begin{array}{ll}\text { Block Dala } & \text { Mitad } \\
12 \times 20 \times 20 & \end{array}$ & 1 & $0.302^{1}$ & 10 & 3.02 \\
\hline \multicolumn{4}{|c|}{$\begin{array}{l}\text { Vigueta V-284 armada con } 2 \varnothing 3 / 16 " \text { y refuerzo } \\
\text { adicional } 1 \text { Ø } 3 / 16 "\end{array}$} & $107.30^{2}$ \\
\hline \multicolumn{4}{|c|}{$\begin{array}{l}\text { Vigueta V-274 armada con } 2 \varnothing 3 / 16 " \text { y refuerzo } \\
\text { adicional } 1 \text { Ø } 3 / 16 "\end{array}$} & $29.58^{2}$ \\
\hline \multicolumn{4}{|c|}{$\begin{array}{l}\text { Vigueta V-234 armada con } 2 \varnothing 3 / 16 " \text { y refuerzo } \\
\text { adicional } 1 \text { Ø } 3 / 16^{\prime \prime}\end{array}$} & $18.94^{2}$ \\
\hline \multicolumn{4}{|c|}{$\begin{array}{l}\text { Vigueta V-095 armada con } 2 \text { Ø 3/16" sin refuerzo } \\
\text { adicional }\end{array}$} & 2.19 \\
\hline
\end{tabular}

Tabla 6 Explosión de insumos de los blocks y las viguetas con la multiplicación de factores de emisión

Source: ${ }^{1}$ Rodríguez. Calculadora de carbono para materiales básicos de construcción de obra gris en Costa Rica, ${ }^{2}$ ver anexos 
In (Rodríguez, 2010) "Emission factors for construction materials" the block of measures $12 \times 19 \times 39 \mathrm{~cm}$ is mentioned, with an emission factor of $0.604 \mathrm{~kg}-\mathrm{CO} 2 /$ unit and having great similarity with the housing block obtained from the explosion of inputs that factor was selected, considering that it is practically the same factor for a $12 \times 20 \times 40 \mathrm{~cm}$ block.

For the blocks with measures $12 \times 20 \times 20$ $\mathrm{cm}$ and $12 \times 10 \times 40 \mathrm{~cm}$ having half the volume compared to the block $12 \times 20 \times 40 \mathrm{~cm}$, half of the emission factor was taken for these cases, as can be seen in table 6 .

\begin{tabular}{|l|r|r|r|r|}
\hline \multicolumn{1}{|c}{ Material Peso } & \multicolumn{1}{c|}{$\begin{array}{c}\mathrm{CO}_{2} / \\
\mathrm{Ud}\end{array}$} & \multicolumn{1}{c|}{ Pzas. } & \multicolumn{1}{c|}{$\begin{array}{l}\text { Total } \\
\mathrm{CO}_{2}\end{array}$} \\
\hline $\begin{array}{l}\text { Varilla Corrugada } \\
\text { de 1/2" }\end{array}$ & 172.23 & $2.8^{1}$ & 1 & 482.24 \\
\hline $\begin{array}{l}\text { Varilla corrugada } \\
\text { de 3/8" }\end{array}$ & 160.79 & $2.8^{1}$ & 1 & 450.21 \\
\hline $\begin{array}{l}\text { Malla } \\
\text { Electrosoldada 6-6/ } \\
\text { 6-6 }\end{array}$ & 1.97 & $2.8^{1}$ & 76.1 & 419.77 \\
\hline $\begin{array}{l}\text { Regla Tubular 1 } \\
\text { 1/2"x4" (6.1 M) }\end{array}$ & 50.7032 & $2.8^{1}$ & 1.17 & 166.1 \\
\hline $\begin{array}{l}\text { Malla } \\
\text { electrosoldada 6x6- } \\
\text { 10/10 }\end{array}$ & 0.97 & $2.8^{1}$ & 58.55 & 159.02 \\
\hline Armex 12x12-4 & 6 & $2.8^{1}$ & 8.2 & 137.76 \\
\hline Alambre recocido & 29.98 & $2.8^{1}$ & 1 & 83.94 \\
\hline $\begin{array}{l}\text { Armex 12-20-4 } \\
\text { (tramo 6m) }\end{array}$ & 6.4 & $2.8^{1}$ & 2.57 & 46.05 \\
\hline $\begin{array}{l}\text { Tubo galvanizado } \\
\text { de 3/4" }\end{array}$ & 1.6875 & $2.8^{1}$ & 6.16 & 29.11 \\
\hline $\begin{array}{l}\text { Perfil Monten } \\
\text { 4MT14 }\end{array}$ & 18.29 & $2.8^{1}$ & 0.28 & 14.34 \\
\hline $\begin{array}{l}\text { Regla tubular de 1" } \\
\text { 2 2" (6.1 M) }\end{array}$ & 25.1259 & $2.8^{1}$ & 0.2 & 14.07 \\
\hline $\begin{array}{l}\text { Solera de 1 1/4" x } \\
\text { 1/4" (6.1 M) }\end{array}$ & 9.48 & $2.8^{1}$ & 0.47 & 12.48 \\
\hline Alambrón de 1/4" & 3.85 & $2.8^{1}$ & 1 & 10.78 \\
\hline $\begin{array}{l}\text { Varilla corrugada } \\
\text { 3/8" }\end{array}$ & 3.42 & $2.8^{1}$ & 0.14 & 1.34 \\
\hline
\end{tabular}

Tabla 7 Explosión de insumos de elementos constituidos de puro acero con la multiplicación de factores de emisión Source: ${ }^{l}$ Mercader. Modelo de cuantificación de las emisiones de $\mathrm{CO}_{2}$ producidas en edificación derivadas de los recursos materiales consumidos en su ejecución.

Table 7 shows how in the case of steel only the weight of each piece of the material was considered, and its resistance was ignored because it does not affect the emission factor.

For the solera and the tubular ruler, the sections were taken with the commercial measures of $6.10 \mathrm{M}$. For the tubular ruler, the caliber No. 8 was selected for analysis.

\begin{tabular}{|c|c|c|c|c|}
\hline Material & Peso & $\mathrm{CO}_{2} / \mathrm{Ud}$. & Pzas. & $\begin{array}{l}\text { Total de } \\
\mathrm{CO}_{2}\end{array}$ \\
\hline Cemento Gris & 1000 & $0.513^{1}$ & 1.55 & 795.15 \\
\hline Cemento Gris & 1000 & $0.513^{1}$ & 0.25 & 128.25 \\
\hline Yeso Mocuzari & 40 & $0.07252528^{2}$ & 6.1 & 17.70 \\
\hline $\begin{array}{l}\text { Cemento } \\
\text { Blanco }\end{array}$ & 50 & $0.513^{1}$ & 0.62 & 15.90 \\
\hline Calhidra Pimacal & 25 & $0.59^{1}$ & 0.06 & 0.885 \\
\hline \multicolumn{4}{|c|}{$\begin{array}{l}\text { Concreto premezclado Autocurable } \mathrm{F}^{\prime} \mathrm{c}=200 \mathrm{Kg} / \mathrm{cm}^{2} \\
\text { T.M.A. } 11 / 2 " \text {, REV. } 10 \mathrm{~cm} .+/-2.5 \mathrm{~cm} \text {. con Tiro } \\
\text { Directo. }\end{array}$} & $1001.18^{3}$ \\
\hline \multicolumn{4}{|c|}{$\begin{array}{l}\text { Concreto premezclado F'c }=200 \mathrm{Kg} / \mathrm{cm}^{2} \text { T.M.A. 3/4" } \\
\text { REV. } 10 \mathrm{~cm}+/-3.5 \mathrm{~cm} \text { Incluye servicio de banda olla }\end{array}$} & $719.32^{3}$ \\
\hline \multicolumn{4}{|c|}{$\begin{array}{l}\text { Concreto premezclado Autocurable } \mathrm{F}^{\prime} \mathrm{c}=150 \mathrm{Kg} / \mathrm{cm}^{2} \\
\text { T.M.A. } 3 / 4 " \text { Rev. } 10 \mathrm{~cm}+/-2.5 \mathrm{~cm} \text {. }\end{array}$} & $322.25^{3}$ \\
\hline
\end{tabular}

Tabla 8 Explosión de insumos de la calhidra, cemento, concreto y yeso con la multiplicación de factores de emisión

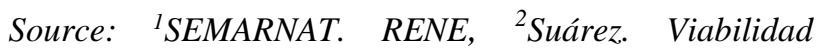
ambiental del reciclaje del yeso, ${ }^{3}$ ver anexos

The cement emission factor observed in table 8 was obtained in the RENE database, the national emission data for each ton of Clinker was determined; considering the ordinary portland cement that is used for the concrete of the beams with a percentage of $95 \%$ of Clinker, the emission factor is obtained. Any difference between the emission factors of white cement, gray compared to ordinary portland, was neglected, since they have the same characteristics.

According to (SEMARNAT \& INECC, 2002) "National Inventory of Emissions of Greenhouse Gases 1990-2002" published in 2002, hydrated lime, hydraulic lime and hydrated aerial lime are reported in the same way, so no distinction was made between them and the same factor was used in table 8 .

\begin{tabular}{|c|c|c|c|c|}
\hline Material & Peso & $\mathrm{CO}_{2} / \mathrm{Ud}$. & Pzas. & Total $\mathrm{CO}_{2}$ \\
\hline $\begin{array}{l}\text { Casetón } \\
1.22 \times 0.61 \times 0.125\end{array}$ & 1.1163 & $3.43^{2}$ & 56 & 214.42 \\
\hline 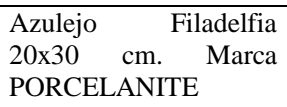 & 1 & $23.22^{1}$ & 5.52 & 128.17 \\
\hline $\begin{array}{l}\text { Azulejo Antiderrapante } \\
\text { Venecia/Cabos de } 20 \\
\mathrm{~cm} \text {. x } 20 \mathrm{~cm} \text { Marca } \\
\text { PORCELANITE }\end{array}$ & 1 & $23.22^{1}$ & 1.14 & 26.47 \\
\hline \begin{tabular}{llrl} 
Malla de & \multicolumn{2}{c}{ Refuerzo } \\
(Rollo de & 100 & m2) \\
KOVER sencilla &
\end{tabular} & 3 & $4.45^{3}$ & 0.55 & 7.34 \\
\hline 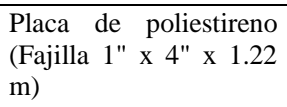 & $\begin{array}{r}0.037 \\
7\end{array}$ & $3.43^{2}$ & 48 & 6.21 \\
\hline $\begin{array}{l}\text { Mortero especial para } \\
\text { pegue } \\
\text { Línea Cement King) } \\
\text { Saco de } 25 \mathrm{~kg} .\end{array}$ & 25 & $0.22268^{1}$ & 0.62 & 3.45 \\
\hline
\end{tabular}

Tabla 9 Explosión de insumos del mortero, azulejo, casetón, placa de poliestireno y malla de refuerzo con la multiplicación de factores de emisión

ACEVES-GUTIERREZ, Humberto, LÓPEZ-CHÁVEZ, Oscar, MERCADO-IBARRA, Santa Magdalena and CONTRERASQUINTANAR, Cesar Alejandro. GHG emissions in KG-CO2 / M2 generated by a House Type INFONAVIT. ECORFAN Journal-Republic of Nicaragua. 2019 


\begin{tabular}{|l|r|r|r|r|}
\hline \multicolumn{2}{|c|}{ Material } & \multicolumn{1}{c|}{$\mathrm{CO}_{2} / \mathrm{Ud}}$. & \multicolumn{1}{c|}{ Pzas. } & Total $\mathrm{CO}_{2}$ \\
\hline $\begin{array}{l}\text { Pintura Vinílica } \\
\text { Rekolor color blanco } \\
\text { o pastel Marca Berel. }\end{array}$ & 27.55 & $2.91^{1}$ & 2.52 & 202.03 \\
\hline $\begin{array}{l}\text { Pintura Elastomerica } \\
\text { Berel, color blanco o } \\
\text { pastel. (Garantía 3 } \\
\text { años) }\end{array}$ & 27.55 & $2.91^{1}$ & 2.46 & 197.22 \\
\hline $\begin{array}{l}\text { Pintura para } \\
\text { molduras }\end{array}$ & 5.49 & $2.91^{1}$ & 1.23 & 19.65 \\
\hline $\begin{array}{l}\text { Pintura de esmalte } \\
\text { anticorrosivo marca } \\
\text { Berel línea Qualik }\end{array}$ & 21.85 & $2.91^{1}$ & 0.04 & 2.54 \\
\hline Pintura Esmalte color & 1.45 & $2.91^{1}$ & 0.33 & 1.39 \\
\hline
\end{tabular}

Tabla 10 Explosión de insumos de la pintura con la multiplicación de factores de emisión

Source: ${ }^{1}$ Hammond \& Jones. ICE

\begin{tabular}{|c|c|c|c|c|}
\hline Material & Peso & $\mathrm{CO}_{2} / \mathrm{Ud}$ & Pzas. & Total $\mathrm{CO}_{2}$ \\
\hline Arena & 1560 & $0.03^{1}$ & 3.49 & 163.33 \\
\hline $\begin{array}{l}\text { Barrote } 2 " \text { x 4" } \\
\text { x } 12^{\prime}\end{array}$ & 1.175 & $2.314^{2}$ & 4.34 & 11.80 \\
\hline $\begin{array}{l}\text { Tablón de 2" x } \\
8 " \text { x 10' }\end{array}$ & 1.1775 & $2.314^{2}$ & 1.53 & 4.17 \\
\hline $\begin{array}{l}\text { Fajilla de } 1 " \text { x } \\
4^{\prime \prime} \times 10^{\prime}\end{array}$ & 0.9 & $2.314^{2}$ & 1.52 & 3.17 \\
\hline $\begin{array}{l}\text { Tablón de 2" x } \\
4 " \text { x } 10 "\end{array}$ & 1.17 & $2.314^{2}$ & 1.1 & 2.98 \\
\hline $\begin{array}{l}\text { Fajilla de } 1^{\prime \prime} \times \\
4^{\prime \prime} \text { x 8 8' }\end{array}$ & 2.5 & $2.314^{2}$ & 0.39 & 2.26 \\
\hline Grava & 1560 & $0.03^{1}$ & 0.04 & 1.87 \\
\hline $\begin{array}{l}\text { Pipa de Agua } \\
\left(7.0 \mathrm{M}^{3}\right)\end{array}$ & 7 & $0.03^{1}$ & 1.4 & 0.29 \\
\hline
\end{tabular}

Tabla 11 Explosión de insumos del agua, los áridos y la madera con la multiplicación de factores de emisión

Source: 'Mercader. Modelo de cuantificación de las emisiones de $\mathrm{CO}_{2}$ producidas en edificación derivadas de los recursos materiales consumidos en su ejecución, ${ }^{2}$ SEMARNAT, Factores de emisión para los diferentes tipos de combustibles fósiles y alternativos que se consumen en México

\begin{tabular}{|c|c|c|c|c|}
\hline Material & Peso & $\begin{array}{l}\mathrm{CO}_{2} / \\
\mathrm{Ud} .\end{array}$ & Pzas. & $\begin{array}{l}\text { Total } \\
\mathrm{CO}_{2}\end{array}$ \\
\hline 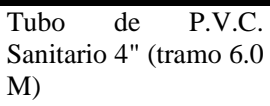 & 6.925 & $3.1^{1}$ & 3.17 & 68.05 \\
\hline $\begin{array}{l}\text { Tubo de P.V.C. de } 2 " \\
\text { (tramo de } 6.0 \mathrm{M} \text { ) }\end{array}$ & 2.275 & $3.1^{1}$ & 1.85 & 13.05 \\
\hline $\begin{array}{l}\text { Tubo de CPVC de } 1 / 2 " \\
\text { (tramo } 3.05 \text { ) }\end{array}$ & 0.38 & $3.1^{1}$ & 7.87 & 9.27 \\
\hline $\begin{array}{l}\text { Tubo de CPVC. de } \\
\text { 3/4" (tramo 6.0 M) }\end{array}$ & 1.24 & $3.1^{1}$ & 0.91 & 3.50 \\
\hline $\begin{array}{l}\text { Tubo de P.V.C. } \\
\text { Sanitario } 1 \text { 1/2" (tramo } \\
6.0 \mathrm{M})\end{array}$ & 1.92 & $3.1^{1}$ & 0.45 & 2.68 \\
\hline $\begin{array}{l}\text { Yee de P.V.C. de 4" a } \\
2^{2}\end{array}$ & 0.214 & $3.1^{1}$ & 2 & 1.33 \\
\hline Tee lisa CPVC 1/2" & 0.031 & $3.1^{1}$ & 12 & 1.15 \\
\hline Tapón CPVC 1/2" & 0.012005 & $3.1^{1}$ & 24 & 0.89 \\
\hline $\begin{array}{l}\text { Codo de P.V.C. de } 2 " \mathrm{x} \\
45^{\circ}\end{array}$ & 0.135 & $3.1^{1}$ & 2 & 0.84 \\
\hline Codo CPVC $1 / 2 "$ x $90^{\circ}$ & 0.01 & $3.1^{1}$ & 25 & 0.78 \\
\hline $\begin{array}{l}\text { Codo de P.V.C. de } 2 " x \\
90^{\circ}\end{array}$ & 0.05 & $3.1^{1}$ & 5 & 0.78 \\
\hline $\begin{array}{l}\text { Cople o Adaptador } \\
\text { macho CPVC } 1 / 2 "\end{array}$ & 0.011 & $3.1^{1}$ & 15 & 0.51 \\
\hline Tee de P.V.C. de 2" & 0.07 & $3.1^{1}$ & 2 & 0.43 \\
\hline $\begin{array}{l}\text { Cople liso CPVC de } \\
1 / 2 "\end{array}$ & 0.007 & $3.1^{1}$ & 7 & 0.15 \\
\hline
\end{tabular}

Tabla 12 Explosión de insumos del PVC y CPVC con la multiplicación de factores de emisión

Source: ${ }^{l}$ Hammond \& Jones. ICE

ISSN 2414-8830

ECORFAN® All rights reserved
June, 2019 Vol.5 No.8 15-28

Se consideró el mismo factor de emisión para el PVC y el CPVC en la tabla 12.

\begin{tabular}{|l|r|l|}
\hline \multicolumn{3}{|c|}{ Emisiones totales en la vivienda } \\
\hline Total en $\mathrm{Kg}-\mathrm{CO}_{2}$ & 7087.95 & $\mathrm{Kg}-\mathrm{CO}_{2}$ \\
\hline Emisión por área & 161.57 & $\mathrm{Kg}-\mathrm{CO}_{2} / \mathrm{M} 2$ \\
\hline
\end{tabular}

Tabla 13 Emisiones totales generadas en la vivienda Source: Own elaboration

Table 13 shows the total $\mathrm{Kg}-\mathrm{CO} 2$ emissions of all the work studied and also shows the result of dividing the previous result in the work area and thus obtaining the emissions in $\mathrm{Kg}-\mathrm{CO} 2$ / M2.

To carry out this investigation, an area of $43.87 \mathrm{M} 2$ of total construction was used, which allowed us to obtain the result of $161.57 \mathrm{Kg}-\mathrm{CO} 2$ / M2.

\section{Annexes}

Annexe 1

\begin{tabular}{|c|c|c|c|c|}
\hline Material & Peso & $\begin{array}{c}\mathrm{CO}_{2} / \\
\mathrm{Ud} .\end{array}$ & Pzas. & $\begin{array}{l}\text { Total } \\
\mathrm{CO}_{2}\end{array}$ \\
\hline $\begin{array}{lr}\text { Malla } & \text { de } \\
\text { Refuerzo } & \text { (Rollo } \\
\text { de } 100 & \text { M2) } \\
\text { KOVER sencilla }\end{array}$ & 3 & $4.45^{1}$ & 0.55 & 7.34 \\
\hline
\end{tabular}

Tabla 14. Factor de emisión de la Malla de Refuerzo. Source: ${ }^{1}$ Pedreño. Desarrollo de una aplicación para el cálculo de la huella de carbono en proyectos de construcción

\section{Anexo 2}

\section{Material} Peso Volumétrico (kg/M3)

\begin{tabular}{l|l} 
Arena grava, seca, suelta & $1440-1680^{1 *}$
\end{tabular}

*Se promedio el valor de los rangos inferior y superior.

Tabla 15 Peso volumétrico de la arena y la grava Source: ${ }^{1}$ Fundidora Monterrey (México). Manual para Constructores

Anexo 3

\begin{tabular}{|l|r|r|r|}
\hline \multicolumn{1}{|c|}{ Material } & \multicolumn{1}{c|}{ Cantidad } & \multicolumn{1}{c|}{$\mathrm{N}^{\circ} \mathrm{M} 3$} & \multicolumn{1}{c|}{ Total } \\
\hline Cemento (kg) & $310^{1}$ & 1.5 & 465.00 \\
\hline Grava (kg) & $1000^{1}$ & 1.5 & 1500.00 \\
\hline Arena (kg) & $860^{1}$ & 1.5 & 1290.00 \\
\hline Agua (lt) & $205^{1}$ & 1.5 & 307.50 \\
\hline
\end{tabular}

Tabla 16 Cantidad total de material para el Concreto premezclado Autocurable F'c $=150 \mathrm{Kg} / \mathrm{CM} 2$ T.M.A. 3/4" Rev. $10 \mathrm{CM}+/-2.5 \mathrm{CM}$

Source: ${ }^{1}$ CEMEX Concretos, Manual del Constructor

ACEVES-GUTIERREZ, Humberto, LÓPEZ-CHÁVEZ, Oscar, MERCADO-IBARRA, Santa Magdalena and CONTRERASQUINTANAR, Cesar Alejandro. GHG emissions in KG-CO2 / M2 generated by a House Type INFONAVIT. ECORFAN Journal-Republic of Nicaragua. 2019 
Anexo 4

\begin{tabular}{|c|c|c|}
\hline Total & Factor de Emisión & $\mathrm{kg} \operatorname{de} \mathrm{CO}_{2}$ \\
\hline $465.00 *$ & $0.513^{1}$ & 238.55 \\
\hline $1500.00 * *$ & $0.03^{2}$ & 45.00 \\
\hline $1290.00 * * *$ & $0.03^{2}$ & 38.70 \\
\hline \multirow[t]{2}{*}{$307.50 * * * *$} & $0.00003^{2}$ & 0.01 \\
\hline & Total & 322.254 \\
\hline
\end{tabular}

Tabla 17 Total, de emisiones para el Concreto premezclado Autocurable F'c $=150 \mathrm{Kg} / \mathrm{CM} 2$ T.M.A. 3/4" Rev. $10 \mathrm{CM}+/-2.5 \mathrm{CM}$.

Source: ${ }^{1}$ SEMARNAT. RENE, ${ }^{2}$ Mercader. Modelo de cuantificación de las emisiones de $\mathrm{CO}_{2}$ producidas en edificación derivadas de los recursos materiales consumidos en su ejecución.

Anexo 5

\begin{tabular}{|l|r|r|r|}
\hline \multicolumn{1}{|c}{ Material } & \multicolumn{1}{c}{ Cantidad } & \multicolumn{1}{c|}{$\mathrm{N}^{\circ} \mathrm{M} 3$} & \multicolumn{1}{c|}{ Total } \\
\hline Cemento (kg) & $305^{1}$ & 4.69 & 1430.45 \\
\hline Grava (kg) & $1000^{1}$ & 4.69 & 4690.00 \\
\hline Arena (kg) & $900^{1}$ & 4.69 & 4221.00 \\
\hline Agua (lt) & $190^{1}$ & 4.69 & 891.10 \\
\hline
\end{tabular}

Tabla 18 Cantidad total de material para el Concreto premezclado Autocurable $\mathrm{F}^{\prime} \mathrm{c}=200 \mathrm{Kg} / \mathrm{CM} 2$ T.M.A. 1 1/2", REV. 10 CM. +/- 2.5 CM. con Tiro Directo Source: ${ }^{1}$ CEMEX Concretos, Manual del Constructor.

Anexo 6

\begin{tabular}{|r|r|r|}
\hline \multicolumn{1}{|l|}{ Total } & \multicolumn{1}{l|}{ Factor de Emisión } & \multicolumn{1}{c|}{$\mathrm{kg} \mathrm{de} \mathrm{CO}_{2}$} \\
\hline $1430.45^{*}$ & $0.513^{1}$ & 733.82 \\
\hline $4690.00^{* *}$ & $0.03^{2}$ & 140.70 \\
\hline $4221.00^{* * *}$ & $0.03^{2}$ & 126.63 \\
\hline $891.10^{* * * *}$ & $0.00003^{2}$ & 0.03 \\
\hline & & 1001.178 \\
\hline
\end{tabular}

*Cemento, **Grava, ***Arena, ****Agua

Tabla 19 Total, de emisiones para el Concreto premezclado Autocurable $\mathrm{F}^{\prime} \mathrm{c}=200 \mathrm{Kg} / \mathrm{CM} 2$ T.M.A. 1 1/2", REV. 10 CM. +/- 2.5 CM. con Tiro Directo

Source: ${ }^{l}$ SEMARNAT. RENE, ${ }^{2}$ Mercader. Modelo de cuantificación de las emisiones de $\mathrm{CO}_{2}$ producidas en edificación derivadas de los recursos materiales consumidos en su ejecución.

Anexo 7

\begin{tabular}{|l|r|r|r|}
\hline \multicolumn{1}{|c|}{ Material } & \multicolumn{1}{c|}{ Cantidad } & \multicolumn{1}{c|}{$\mathrm{N}^{\circ} \mathrm{M} 3$} & \multicolumn{1}{c|}{ Total } \\
\hline Cemento $(\mathrm{kg})$ & $350^{1}$ & 3.07 & 1074.50 \\
\hline Grava $(\mathrm{kg})$ & $1000^{1}$ & 3.07 & 3070.00 \\
\hline Arena $(\mathrm{kg})$ & $825^{1}$ & 3.07 & 2532.75 \\
\hline Agua (lt) & $205^{1}$ & 3.07 & 629.35 \\
\hline
\end{tabular}

Tabla 20 Cantidad total de material para el Concreto premezclado $\mathrm{F}^{\prime} \mathrm{c}=200 \mathrm{Kg} / \mathrm{CM} 2$ T.M.A. 3/4" REV. 10 $\mathrm{CM}+$ +- 3.5 CM Incluye servicio de banda olla

Source: ${ }^{1}$ CEMEX Concretos, Manual del Constructor
Anexo 8

\begin{tabular}{|c|c|c|}
\hline Total & Factor de Emisión & $\mathrm{kg}$ de $\mathrm{CO}_{2}$ \\
\hline $1074.50 *$ & $0.513^{1}$ & 551.219 \\
\hline $3070.00 * *$ & $0.03^{2}$ & 92.100 \\
\hline $2532.75 * * *$ & $0.03^{2}$ & 75.983 \\
\hline $629.35 * * * *$ & $0.00003^{2}$ & 0.019 \\
\hline & Total & 719.320 \\
\hline
\end{tabular}

Tabla 21 Total, de emisiones para el Concreto premezclado $F^{\prime} \mathrm{c}=200 \mathrm{Kg} / \mathrm{CM} 2$ T.M.A. 3/4" REV. 10 $\mathrm{CM}+/-3.5 \mathrm{CM}$ Incluye servicio de banda olla

Source: ${ }^{1}$ SEMARNAT. RENE, ${ }^{2}$ Mercader. Modelo de cuantificación de las emisiones de $\mathrm{CO}_{2}$ producidas en edificación derivadas de los recursos materiales consumidos en su ejecución.

Anexo 9

Concreto $\mathrm{F}^{\prime} \mathrm{c}=250 \mathrm{Kg} / \mathrm{cm} 2$ para cada M3, tamaño
máximo $20 \mathrm{~mm}(3 / 4 ")$

Tabla 22 Cantidad de material para el concreto de la vigueta V-274 armada con 2 Ø 3/16" y refuerzo adicional 1 Ø $3 / 16 "$

Source: ${ }^{1}$ CEMEX Concretos, Manual del Constructor

Anexo 10

\begin{tabular}{|}
$\mid \begin{array}{r}\text { Concreto } \mathrm{F}^{\prime} \mathrm{c}=250 \mathrm{Kg} / \mathrm{cm} 2 \text { para cada } \mathrm{M} 3 \text {, tamaño } \\
\text { máximo } 20 \mathrm{~mm}(3 / 4 ")\end{array}$ \\
\hline \multicolumn{1}{|c|}{ Total } & \multicolumn{1}{|c|}{$\mathrm{F}$. Emisión } & \multicolumn{1}{|c|}{$\mathrm{Kg} \mathrm{de} \mathrm{CO}_{2}$} \\
\hline $6.41^{*}$ & $0.513^{1}$ & 3.289 \\
\hline $16.44 * *$ & $0.03^{2}$ & 0.493 \\
\hline $12.99 * * *$ & $0.03^{2}$ & 0.390 \\
\hline $3.37 * * * *$ & $0.00003^{2}$ & 0.000 \\
\hline *Cemento, **Grava, ***Arena, ****Agua
\end{tabular}

Tabla 23 Total, de emisión del concreto de la vigueta V274 armada con 2 Ø 3/16" y refuerzo adicional 1 Ø 3/16" Source: ${ }^{1}$ SEMARNAT. RENE, ${ }^{2}$ Mercader. Modelo de cuantificación de las emisiones de $\mathrm{CO}_{2}$ producidas en edificación derivadas de los recursos materiales consumidos en su ejecución

\section{Anexo 11}

\begin{tabular}{|l|r|r|r|r|}
\hline Material & $\mathrm{kg} / \mathrm{ML}$ & $\mathrm{N}^{\circ}$ de $\mathrm{M}$ & \multicolumn{2}{|c|}{ F. Emisión $\mathrm{Kg}$ de $\mathrm{CO}_{2}$} \\
\hline Acero & $0.14^{1}$ & 8.22 & $2.8^{2}$ & 3.22 \\
\hline
\end{tabular}

Tabla 24 Cantidad de material de acero para la vigueta V274 armada con 2 Ø 3/16" y refuerzo adicional 1 Ø 3/16 Source: 'Salazar. Costo y tiempo en edificación, ${ }^{2}$ Mercader. Modelo de cuantificación de las emisiones de $\mathrm{CO}_{2}$ producidas en edificación derivadas de los recursos materiales consumidos en su ejecución

ACEVES-GUTIERREZ, Humberto, LÓPEZ-CHÁVEZ, Oscar, MERCADO-IBARRA, Santa Magdalena and CONTRERASQUINTANAR, Cesar Alejandro. GHG emissions in KG-CO2 / M2 generated by a House Type INFONAVIT. ECORFAN Journal-Republic of Nicaragua. 2019 
Anexo 12

\begin{tabular}{|r|r|r|}
\hline $\mathrm{Kg}$ de $\mathrm{CO}_{2}$ & $\mathrm{~N}^{\circ}$ Piezas & Total de $\mathrm{CO}_{2}$ \\
\hline 7.39 & & 4 \\
\hline
\end{tabular}

Tabla 25 Total, de emisiones de las viguetas V-274 armada con 2 Ø 3/16" y refuerzo adicional 1 Ø 3/16" Source: Own Elaboration

Anexo 13

\begin{tabular}{|c|c|c|c|}
\hline \multicolumn{4}{|c|}{$\begin{aligned} \text { Concreto } \mathrm{F}^{\prime} \mathrm{c} & =250 \mathrm{Kg} / \mathrm{cm} 2 \text { para cada M3, tamaño } \\
& \text { máximo } 20 \mathrm{~mm}\left(3 / 4^{\prime \prime}\right)\end{aligned}$} \\
\hline Material & Cant. & $\begin{array}{c}\mathrm{N}^{\circ} \text { de } \\
\text { M3/vigueta }\end{array}$ & Total \\
\hline Cemento (kg) & $390^{1}$ & 0.0057 & 2.22 \\
\hline Grava (kg) & $1000^{1}$ & 0.0057 & 5.70 \\
\hline Arena $\mathrm{n}^{\circ} 4(\mathrm{~kg})$ & $790^{1}$ & 0.0057 & 4.50 \\
\hline Agua (lt) & $205^{1}$ & 0.0057 & 1.17 \\
\hline
\end{tabular}

Tabla 26 Cantidad de material para el concreto de la vigueta V-095 armada con $2 \varnothing 3 / 16 "$ sin refuerzo adicional Source: ${ }^{1}$ CEMEX Concretos, Manual del Constructor

Anexo 14

\begin{tabular}{|c|c|c|}
\hline \multicolumn{3}{|c|}{$\begin{aligned} & \text { Concreto } \mathrm{F}^{\prime} \mathrm{c}=250 \mathrm{Kg} / \mathrm{cm} 2 \text { para cada } \mathrm{M} 3, \text { tamaño } \\
& \text { máximo } 20 \mathrm{~mm}\left(3 / 4^{\prime \prime}\right)\end{aligned}$} \\
\hline Total & F. Emisión & $\mathrm{Kg}$ de $\mathrm{CO}_{2}$ \\
\hline $2.22 *$ & $0.513^{1}$ & 1.14 \\
\hline $5.70 * *$ & $0.03^{2}$ & 0.17 \\
\hline $4.50 * * *$ & $0.03^{2}$ & 0.14 \\
\hline 1.17 **** & $0.00003^{2}$ & 0.00 \\
\hline
\end{tabular}

Tabla 27 Total, de emisión del concreto de la vigueta V095 armada con $2 \varnothing 3 / 16 "$ sin refuerzo adicional Source: ${ }^{1}$ SEMARNAT. RENE, ${ }^{2}$ Mercader. Modelo de cuantificación de las emisiones de $\mathrm{CO}_{2}$ producidas en edificación derivadas de los recursos materiales consumidos en su ejecución.

\section{Anexo 15}

\begin{tabular}{|c|c|c|c|c|}
\hline Material & $\mathrm{kg} / \mathrm{ML}$ & $\begin{array}{c}\mathrm{N}^{\circ} \text { de } \\
\mathrm{M}\end{array}$ & F. Emisión & $\begin{array}{c}\mathrm{Kg} \text { de } \\
\mathrm{CO}_{2}\end{array}$ \\
\hline & & 1.9 & $2.8^{2}$ & 0.74 \\
\hline
\end{tabular}

Tabla 28 Cantidad de material de acero para la vigueta V095 armada con 2 Ø 3/16" sin refuerzo adicional

Source: 'Salazar. Costo y tiempo en edificación, ${ }^{2}$ Mercader. Modelo de cuantificación de las emisiones de $\mathrm{CO}_{2}$ producidas en edificación derivadas de los recursos materiales consumidos en su ejecución.

Anexo 16

\begin{tabular}{|r|r|r|}
\hline $\mathrm{Kg}$ de $\mathrm{CO}_{2}$ & \multicolumn{1}{|c|}{$\mathrm{N}^{\circ}$ Piezas } & Total de $\mathrm{CO}_{2}$ \\
\hline 2.19 & 1 & 2.19 \\
\hline
\end{tabular}

Tabla 29 Total de emisiones de la vigueta V-095 armada con $2 \varnothing 3 / 16^{\prime \prime}$ sin refuerzo adicional

Source: Own Elaboration
Anexo 17

\begin{tabular}{|c|c|c|c|c|}
\hline Material & $\mathrm{kg} / \mathrm{ML}$ & $\begin{array}{c}\mathrm{N}^{\circ} \mathrm{de} \\
\mathrm{M}\end{array}$ & F. Emisión & $\begin{array}{c}\mathrm{Kg} \text { de } \\
\mathrm{CO}_{2}\end{array}$ \\
\hline & $0.14^{1}$ & 7.02 & $2.8^{2}$ & 2.75 \\
\hline
\end{tabular}

Tabla 30 Cantidad de material para el concreto de la vigueta V-234 armada con 2 Ø 3/16" y refuerzo adicional 1 Ø $3 / 16 "$

Source: ${ }^{1}$ CEMEX Concretos, Manual del Constructor

Anexo 18

\begin{tabular}{|c|c|c|}
\hline \multicolumn{3}{|c|}{$\begin{aligned} & \text { Concreto } \mathrm{F}^{\prime} \mathrm{c}=250 \mathrm{Kg} / \mathrm{cm} 2 \text { para cada } \mathrm{M} 3, \text { tamaño } \\
& \text { máximo } 20 \mathrm{~mm}\left(3 / 4^{\prime \prime}\right)\end{aligned}$} \\
\hline Total & F. Emisión & $\mathrm{Kg} \mathrm{de} \mathrm{CO}_{2}$ \\
\hline $5.48 *$ & $0.513^{1}$ & 2.809 \\
\hline $14.04 * *$ & $0.03^{2}$ & 0.421 \\
\hline $11.09 * * *$ & $0.03^{2}$ & 0.333 \\
\hline $2.88 * * * *$ & $0.00003^{2}$ & 0.000 \\
\hline
\end{tabular}

Tabla 31 Total de emisión del concreto de la vigueta V234 armada con 2 Ø 3/16" y refuerzo adicional 1 Ø 3/16" Source: ' $S E M A R N A T$. RENE, ${ }^{2}$ Mercader. Modelo de cuantificación de las emisiones de $\mathrm{CO}_{2}$ producidas en edificación derivadas de los recursos materiales consumidos en su ejecución

Anexo 19

\begin{tabular}{|l|r|r|r|}
\hline \multicolumn{4}{|c|}{ Concreto F'c $=250 \mathrm{Kg} / \mathrm{cm} 2$ para cada M3, tamaño } \\
máximo $20 \mathrm{~mm}\left(3 / 4^{\prime \prime}\right)$
\end{tabular}

Tabla 32 Cantidad de material de acero para la vigueta V234 armada con 2 Ø 3/16" y refuerzo adicional 1 Ø 3/16"

Anexo 20

\begin{tabular}{|r|r|r|}
\hline \multicolumn{1}{|c|}{$\mathrm{Kg}^{\circ}$ de $\mathrm{CO}_{2}$} & \multicolumn{1}{c|}{ Total de $\mathrm{CO}_{2}$} \\
\hline 6.31 & 3 & 18.94 \\
\hline
\end{tabular}

Tabla 33 Total de emisiones de la vigueta V-234 armada con 2 Ø 3/16" y refuerzo adicional $1 \varnothing 3 / 16 "$

Source: Own elaboration

\section{Conclusions}

Based on our results, it was observed that the large emission factors do not influence as much as one would think, but the main factor that manages to increase the total emissions is the volume and quantity of material, since the elements with the greatest amount of weight and / or pieces are those that have a greater number of emissions.

ACEVES-GUTIERREZ, Humberto, LÓPEZ-CHÁVEZ, Oscar, MERCADO-IBARRA, Santa Magdalena and CONTRERASQUINTANAR, Cesar Alejandro. GHG emissions in KG-CO2 / M2 generated by a House Type INFONAVIT. ECORFAN Journal-Republic of Nicaragua. 2019 
An example was that of sand that even with the lowest emission factor was found well above the average, due to its large volume used.

\begin{tabular}{|l|r|r|r|r|}
\hline Material & \multicolumn{1}{c}{ Peso } & \multicolumn{1}{c}{$\mathrm{CO}_{2} / \mathrm{Ud}}$. & \multicolumn{1}{c|}{ Pzas. } & \multicolumn{1}{c|}{ Total $\mathrm{CO}_{2}$} \\
\hline Arena & 1560 & $0.03^{1}$ & 3.49 & 163.332 \\
\hline
\end{tabular}

Tabla 34 Emisiones totales de la arena

Source: ${ }^{1}$ Mercader. Modelo de cuantificación de las emisiones de $\mathrm{CO}_{2}$ producidas en edificación derivadas de los recursos materiales consumidos en su ejecución

Even so, the materials with the highest emission factor are above the median of the number of emissions. But, taking the above that the amount is more important, we can see the example of the PVC parts used that were still the third largest emission factor are those that least contributed to the total emissions.

\begin{tabular}{|l|r|r|r|c|}
\hline \multicolumn{1}{|c|}{ Material Peso } & $\mathrm{CO}_{2} / \mathrm{Ud}$. & Pzas. & $\begin{array}{c}\text { Total } \\
\mathrm{CO}_{2}\end{array}$ \\
\hline $\begin{array}{l}\text { Cople o } \\
\text { Adaptador } \\
\text { macho CPVC } \\
1 / 2 "\end{array}$ & 0.011 & $3.1^{1}$ & 15 & 0.5115 \\
\hline $\begin{array}{l}\text { Tee de P.V.C. } \\
\text { de 2" }\end{array}$ & 0.07 & $3.1^{1}$ & 2 & 0.434 \\
\hline $\begin{array}{l}\text { Cople liso } \\
\text { CPVC de 1/2" }\end{array}$ & 0.007 & $3.1^{1}$ & 7 & 0.1519 \\
\hline
\end{tabular}

Tabla 35 Emisiones parciales de las piezas de PVC y CPVC

Source: ${ }^{1}$ Hammond \& Jones. ICE

What tells us that it is not enough to have a low emission factor, we must also be responsible for the amount of material that we will use and the opposite case is that elements with high emission factors can be used, if they are used in very small quantities, although it would be best to look for an alternative with a lower emission factor and thus emissions in that case could be almost nil.

In particular, it is likely that the impact of $7087.95 \mathrm{Kg}-\mathrm{CO} 2$ / housing or $161.57 \mathrm{Kg}-\mathrm{CO} 2$ / M2 are not as representative individually, however, by performing the analysis presented below, we can measure the magnitude of future impacts.

With the results obtained of $7087.95 \mathrm{Kg}$ $\mathrm{CO} 2$ / per house related to the estimated number of new homes that will be in 2030 compared to 2018 in Sonora, that is, 196,377; The number of new homes in 12 years will generate $1,391,910,357.15 \mathrm{Kg}-\mathrm{CO} 2$ that extrapolated nationally generated emissions pass to critical levels.
So you should start asking and reflecting on what to do to minimize the damage that will cause all these emissions to the atmosphere and the inhabitants of our planet.

Carbon footprint reduction and compensation measures must be implemented in construction projects.

Carbon neutrality is the condition in which the GHG emissions that are reduced and compensated are equal to the GHG emissions generated. Consequently, net GHG emissions are equal to zero.

Another option is to offset their emissions through financial support for some emission reduction project, such as forest conservation and restoration projects, wind farm projects or solar park projects (Estrada, 2014).

It is essential to become aware immediately as global warming can become irreversible, as mentioned in the UN News portal (2019), "The special report of the Intergovernmental Panel on Climate Change revealed in 2018 that it is necessary to limit the global warming at $1.5^{\circ} \mathrm{C}$ to avoid irreversible changes in the life of the planet "; which is an urgent call to take the data provided by that study and begin to design clear strategies, with very well defined objectives, which allow quantifying, reducing and counteracting the emissions that are caused in the construction of houses.

\section{References}

Anónimo. "Comparative life cycle assessment study. 3 cleaning products for kitchen surfaces. French study". PROCTER \& GAMBLE. Brussels innovation Center, Central Product Safety. Noviembre 2004

Argüello Méndez, T. D. R., \& Cuchí Burgos, A. (2008). Análisis del impacto ambiental asociado a los materiales de construcción empleados en las viviendas de bajo coste del programa 10x 10 con Techo-Chiapas del CYTED. Informes de la Construcción, 60(509), 25-34.

Badilla Arroyo, P., Elizondo Santiago, J. A., Fernández Martínez, T., Mora Solano, F., Méndez Trejos, J., \& Quesada Yamasaki, M. (2015). CO2e: cálculo de huella de carbono para materiales de construcción en Costa Rica.

ACEVES-GUTIERREZ, Humberto, LÓPEZ-CHÁVEZ, Oscar, MERCADO-IBARRA, Santa Magdalena and CONTRERASQUINTANAR, Cesar Alejandro. GHG emissions in KG-CO2 / M2 generated by a House Type INFONAVIT. ECORFAN Journal-Republic of Nicaragua. 2019 
Ballester, F. (2005). Contaminación atmosférica, cambio climático y salud. Revista Española de Salud Pública, 79, 159-175.

Bravo, R. (2011). El sector de la construcción genera el 36\% de las emisiones de CO2 en la Unión Europea. mayo 01, 2019, de dicyt Sitio web: http://www.dicyt.com/noticias/el-sectorde-la-construccion-genera-el-36-de-lasemisiones-de-co2-en-la-union-europea

Casanovas, X. (2009). La construcción sostenible: una mirada estratégica. Extraído el, 13 .

CEMEX Concretos. (2003). Manual del constructor. México: CEMEX.

Circular Ecology (2019)- Embodied energy and carbon - The ICE database. Recuperado el 6 de junio 2019

de http://www.circularecology.com/embodiedenergy-and-carbon-footprint-

database.html\#.XPndNdJKilt

CONAPO (2018). Indicadores Demográficos de México de 1950-2050.Recuperado de http://www.conapo.gob.mx/work/models/CON APO/Mapa_Ind_Dem18/index_2.html

Echeverri Londoño, C. A. (2006). Estimación de la emisión de gases de efecto invernadero en el municipio de Montería (Córdoba, Colombia). Revista Ingenierías Universidad de Medellín, 5(9), 85-96.

Estrada Garita, L. C. (2014). Implementación de medidas de reducción y compensación de huella de carbono en proyectos constructivos de la empresa constructora EDIFICAR SA.

Fundidora Monterrey (México). (1977). Manual para constructores. México: Fundidora Monterrey.

González Sánchez, Y., Fernández Díaz, Y., \& Gutiérrez Soto, T. (2013). El cambio climático y sus efectos en la salud. Revista Cubana de Higiene y Epidemiología, 51(3), 331-337.

Hammond, G. P., \& Jones, C. I. (2008). Embodied energy and carbon in construction materials. Proceedings of the Institution of Civil Engineers-Energy, 161(2), 87-98.
INEGI. (2005). II Conteo de Población y Vivienda 2005. junio 16, 2019, de INEGI Sitio web: https://www.inegi.org.mx/programas/ccpv /2005/

INEGI. (2010). Censo de Población y Vivienda 2010. junio 16, 2019, de INEGI Sitio web: https://www.inegi.org.mx/programas/ccpv/2010

INEGI. (2015). Encuesta Intercensal 2015. junio 16, 2019, de INEGI Sitio web: https://www.inegi.org.mx/programas/intercensa $1 / 2015 /$

Menghi, C. I. (2007). Calentamiento global: el riesgo oculto para la salud. Revista argentina de microbiología, 39(3), 131-132.

Mercader, M. P., de Arellano, A. R., \& Olivares, M. (2012). Modelo de cuantificación de las emisiones de $\mathrm{CO}_{2}$ producidas en edificación derivadas de los recursos materiales consumidos en su ejecución. Informes de la Construcción, 64(527), 401-414.

Montaño Arias, N. M., \& Sandoval Pérez, A. L. (2007). Contaminación atmosférica y salud.

Noticias ONU. (2019). Todos los dirigentes de la ONU piden planes urgentes contra el cambio climático. mayo 23, 2019, de Noticias ONU Sitio web: https://news.un.org/es/story/2019/05/1455732

Pedreño Manresa, A. (2015). Desarrollo de una aplicación para el cálculo de la huella de carbono en proyectos de construcción.

Rodríguez Durón, C. (2010). Calculadora de carbono para materiales básicos de construcción de obra gris en Costa Rica. Proyecto de Graduación - Licenciatura en Ingeniería en Construcción, Instituto Tecnológico de Costa Rica, Cartago, Costa Rica.

Salazar, C. S., \& Suarez, C. (1978). Costo y tiempo en edificación. Editorial Limusa.

SEMARNAT \& INECC. (2002). Inventario Nacional de Emisiones de Gases de Efecto Invernadero 1990-2002. 10 de Junio de 2019, de SEMARNAT \& INECC Sitio web: http://www2.inecc.gob.mx/descargas/cclimatico /mexico_nghgi_2002.pdf 
SEMARNAT, , 2010, con base en: Instituto Nacional de Ecología, Sistema Integrado de Regulación Directa y Gestión Ambiental de la Industria, Segunda edición, SEMARNAP / INE, México, 1997. SEMARNAP, Gestión ambiental hacia la Industria, $1^{\mathrm{a}}$ edición, SEMARNAP, México, 2000.

SEMARNAT, Integración y actualización del Inventario Nacional de Generación de Residuos Peligrosos, $1^{\text {a }}$ edición, SEMARNAT, México, 2010.http://dgeiawf.semarnat.gob.mx:8080/ibi_ apps/WFServlet?IBIF_ex=D2_R_INDUSTRIA 01_01\&IBIC_user=dgeia_mce\&IBIC_pass=dg eia_mce

SEMARNAT. (2019). Registro Nacional de Emisiones (RENE). Recuperado el 6 de junio 2019

de https://www.gob.mx/semarnat/acciones-yprogramas/registro-nacional-de-emisiones-rene

Serrano, M. S. G. (2019). Consumo privado de los hogares y emisiones de gases de efecto invernadero en España. Índice. Revista de Estadística y Sociedad, 2019, vol. 72, p. 25-27.

Shen, L. Y., Lu, W. S., Yao, H., \& Wu, D. H. (2005). A computer-based scoring method for measuring the environmental performance of construction activities. Automation in Construction, 14(3), 297-309.

World Resources Institute and the World Business Council for Sustainable Development. (2019). About us. junio 16, 2019, de GREENHOUSE GAS PROTOCOL Sitio web: https://ghgprotocol.org/about-us 